\title{
Intersectoral Tax Burdens in Pakistan: A Critical Review of Existing Evidence and Some New Estimates
}

\author{
SHAHNAZ KAZI*
}

The study has two objectives: to evaluate existing empirical work on the subject of sectoral tax burdens, and to present alternative estimates of relative tax capacity and tax burden for the farm and non-farm sectors during the Seventies. The results indicate that whereas the agricultural sector as a whole was overtaxed compared to the non-agriculture sector, the higher income groups in the farm sector were substantially undertaxed as compared to their urban counterparts. This fact reflects the extreme regressiveness of the agrarian tax structure in the absence of an effective direct tax on agricultural income.

Taxation of the agricultural sector is a major instrument for mobilization of the surplus and redistribution of income in the economy, the two most crucial problems facing developing countries today. Agriculture, by virtue of the fact that it is the largest sector in most of the developing countries, is expected to make a significant contribution to the resource mobilization effort in the public sector. The importance of agricultural taxation in the development literature also derives from its role as a major mechanism for transferring resources from agriculture to finance the expansion of industrial investment. Mobilization of agricultural surpluses through tax policy or changes in intersectoral terms of trade has played a vital role in the development policy of several centrally planned economies as well as a number of capitalist countries.

Apart from considerations of economic objectives, a strong case can be made for comparable tax treatment of agriculture on the basis of the traditional fiscal canon of equity which "demands that the burden involved in rapid economic development be distributed equally among the different sections of the population" $[4$, p. 67]. There are two aspects of equity; tax-paying units in similar economic conditions should be treated equally (horizontal equity), whereas those with greater ability to pay should bear a greater tax burden (vertical equity) whatever the sectoral origins of the income.

*The author is Research Economist at the Pakistan Institute of Development Economics, Islamabad. This paper is a part of the Ph.D. dissertation submitted to the University of London. The author is grateful to her supervisor, Mr. T.J. Byres, for his guidance. 
Thus, in theory, taxation of agriculture is expected to make a substantial contribution to government savings on the basis of both economic and equity criteria. Yet despite its importance the subject has been largely neglected in empirical research on Pakistan's economy. This paper attempts to provide a sounder empirical basis to the question of agriculture's contribution to tax revenue. It will do so, first, by a critical review of existing work on the subject of sectoral tax burdens for the Pakistani economy. Secondly, independent estimates of incidence of taxation by sectors will be derived from the period from 1972-73 to 1979-80. These estimates, along with available empirical research, will be used to determine whether the farm sector is undertaxed vis- $a$-vis non-agriculture and, even more importantly, whether income classes in the agricultural sector are undertaxed compared to income classes in the non-farm sector.

\section{METHODOLOGICAL FRAMEWORK}

Intersectoral tax burdens are usually compared on the basis of the equity criteria. Here it should be mentioned again that an equitable tax structure has to satisfy two conditions; the canon of horizontal equity, which entails that units with equal taxable capacity be treated identically, and the principle of vertical equity, which requires that the tax burden should increase with the level of income according to some socially acceptable rate.

Tax burden is measured as the ratio of taxes, incorporating all taxes direct as well as indirect, to taxable capacity. Two different concepts are used to measure taxable capacity - income per capita and income less subsistence requirements per capita. Due to problems, empirical and conceptual, in estimating basic subsistence levels the ratio of taxes to income per capita, although a less accurate concept, is the more widely used measure. However, since the measure does not allow for any progression in tax rates, it does not fulfil the requirements of vertical equity when comparisons between unequal economic units are involved. To remedy this limitation, an alternative index was put forward by Frank [5]. Tax burden was now defined as the ratio of taxes as a proportion of income to income per capita. Hence, in cases where income levels differed and the standard measure indicated equal sacrifice as reflected in the tax-income ratio, Frank's index would show a lower sacrifice for the higher income.

However, this measure has been criticised by Gandhi [6] for giving an unduly high weight to income, thereby incorporating "too much progression" justifiable only when there is an extremely large degree of dispersion in income levels. $\mathrm{He}$ suggested an improvement of the measure whereby the degree of progression was not fixed and could be specified in accordance with the variation in the incomes being compared. The index was of the following form:
$B=t / y^{e o}$
where
$t$ is tax per capita,
$y$ is income per capita, and
eo represents the level of progression.

Thus Frank's measure, where $e o=2$, becomes a specific case of this general form. Gandhi used the value of $e o=1.5$ to represent the rate of progression appropriate for the level of disparity in rural and urban incomes in India. This value of $e o$ has since been used in a number of more recent estimates of the sectoral distribution of tax burdens in the Indian economy [22, p. 208]

\section{CRITICAL REVIEW OF EMPIRICAL LITERATURE ON INTERSECTORAL TAX BURDENS IN PAKISTAN}

The empirical work on intersectoral tax burdens for Pakistan is limited to three studies, two of which pertain to the late Sixties while the third is for the year 1972-73. These studies display some variation in the methodological framework used for estimating sectoral tax burdens. Hamid's assessment of rural-urban tax burdens [7] relies mainly on a comparison of the ratio of direct taxes to income in the two sectors. The lower direct tax-income ratio in the farm sector is the basis of the study's conclusion that agriculture is undertaxed. The distribution of indirect taxes between the rural and urban sectors has been estimated through an incomplete method. Data from the Household Income and Expenditure Survey have been used to show the higher per capita expenditure by urban households on excisable commodities such as sugar, tobacco, fats and oils as compared to the expenditure by their rural counterparts. This observation on the sectoral consumption patterns is considered sufficient to deduce a higher per capita contribution of the urban sector to indirect taxes. No attempt is made to systematically allocate indirect taxes between sectors incorporating differences not only in per capita expenditure on tax commodities by rural and urban households but also in sectoral populations. Finally, Hamid's conclusion that agriculture bears a disproportionately small share of taxes is based on a comparison of average tax rates. Given the disparity in rural and urban incomes, the use of the measure neglects the norm of vertical equity which would require a higher tax rate on the higher-income sector.

An alternative estimate of sectoral tax burdens for the late Sixties provided by Chaudhry [3] shows, contrary to Hamid's results for the same period, that agriculture was overtaxed in relation to its capacity to pay. Chaudhry's estimates of the rural-urban breakdown of tax revenue rest on firmer empirical ground to the extent that the money burden of both direct and indirect taxes is incorporated Indirect taxes are apportioned between sectors on the basis of a percentage 
computed in an IBRD report. According to this estimate [24, p. 6], 27 percent of all indirect taxes are borne by the agricultural sector.

Comparing the tax-income ratios with the ratio of income per worker in the two sectors, the author concludes that agriculture is relatively overtaxed. The measure of intersectoral equity used is based on Frank's method which estimates tax burden as a ratio of tax as a proportion of income to income per worker. As mentioned earlier, this method has been criticised for assigning too large a weight to income. Hence, comparisons of tax burdens using this method would tend to overestimate the relative sacrifice of the low-income sector, in this case agriculture. In contrast to Hamid's study where the comparison of sectoral tax burdens was based on the principle of proportional taxation, Chaudhry's assessment of relative burdens incorporates a greater degree of progression in tax rates than is warranted by the differential in sectoral incomes.

The usefulness of studies, such as those discussed above, in which the case for increased taxation of agriculture is based on grounds of intersectoral equity has been questioned by recent writings on the subject. It is argued that the approach does not present a comprehensive picture of intersectoral burdens since it ignores the many government policies which affect transfer of resources between sectors through non-tax measures such as foreign exchange policy, price policy, etc.

In the context of Pakistan, the system of multiple exchange rates was considered the major instrument used to maintain unfavourable prices for farm products. Under this system, the earnings of agricultural exports were assessed at the artificially low official exchange rate while industrial exports received a more favourable rate. Industrialists could also import their machinery requirements at the cheaper official rate.

The few empirical estimates of resource transfers attributed to non-tax policies, for the late Sixties, provide contradictory results. Hamid [7] has quantified the resource flow attributable to price policy as the difference between disguised taxes on agricultural output and subsidies on inputs. ${ }^{1}$ His results show that implicit and direct subsidies to agriculture outweighed the net effect of disguised taxes, leading to a net transfer of Rs. 1150 million in favour of agriculture in 1968-69. An alternative estimate is provided in a World Bank Study [24, pp. 9-10] according to which the net outflow from agriculture amounted to Rs. 500-900 million in 1969-70.

However, the emphasis in these studies on world prices as a benchmark for measuring the level of resource outflow/inflow attributable to price policy has underplayed the impact of changes in domestic terms of trade on the intersectoral transfer of resources. The terms of trade moved in favour of agriculture throughout

${ }^{1}$ Disguised taxes are estimated as the difference between world prices of farm output at the scarcity and actual exchange rate, while subsidies to the sector include direct subsidies as well as indirect subsidies through underpricing of public utilities such as irrigation water. the Sixties; yet their impact on the transfer of resources has not been incorporated in either estimate. Hence, on the basis of available evidence no conclusive statement can be made on the direction and magnitude of resource flows in the mid-Sixties and late Sixties through non-tax policies.

Although no estimate of intersectoral resource transfer is available for the Seventies, changes in certain major policies indicate that the flow of resources from agriculture must have declined considerably during this period. The devaluation of the rupee in May 1972 ended the discriminatory treatment of agricultural exports. Procurement prices of major crops were raised four times in the five years from 1972 to 1977. Agriculture's terms of trade registered a sharp increase during the period. In view of these developments, the argument that non-tax policies work to the detriment of the farm sector can no longer be considered relevant.

For the Seventies, a valuable contribution to the analysis of tax incidence is made by Jeetun whose study [10] provides the only estimates of inter-class tax burdens by the rural and urban sectors for Pakistan's economy during the period under reference. The comparison of tax burdens between classes is made on the basis of average tax rates, a perfectly appropriate method when comparisons between equal incomes are involved. The results presented in Table 1 indicate that the higher-income groups in the farm sector are greatly undertaxed not only vis-a-vis their urban counterparts but also vis-a-vis the low-income rural households. The predominance of indirect taxes had led to a very low level of progressivity of the rural tax structure, reflected in the smaller degree of variation of effective tax rates over income classes in the sector. While the effective tax rate in the urban sector varies from a low of 8.19 percent to a peak of 33.42 percent, the corresponding tax rates for the rural sector vary from 7.8 percent to 10.66 percent. Hence, the presence of horizontal inequity to the advantage of the rural sector is especially marked for the highest-income groups. The average tax rate for this class in the urban sector is more than three times the rate for the comparable income group in the rural sector.

A drawback of these estimates is the exclusion of provincial taxes and, thereby, of land revenue, the major direct tax on agriculture. Since land revenue, a proportional tax, has far greater impact on low-income group, its omission would mainly affect comparisons of effective tax rates for the lower strata of the urban and rural sectors, especially since the low-income groups in the urban sector are not liable to any direct tax payments. In the case of high-income groups, the incorporation of land revenue would only lead to a marginal reduction in the differential in tax burdens, as is shown in the study.

It is necessary to point out that these results, if anything, understate the differential in tax burdens between the two sectors due to the fact that Jeetun has overestimated the share of the rural sector in total taxes. Thus, his findings show 
Table 1

Effective Tax Rates by Income Classes in the Urban and Rural Sectors - 1972-73

\begin{tabular}{|c|c|c|c|c|c|c|c|c|}
\hline \multirow{2}{*}{$\begin{array}{l}\text { Monthly } \\
\text { Household } \\
\text { Income } \\
\text { (Rs.) }\end{array}$} & \multicolumn{4}{|c|}{ Urban } & \multicolumn{4}{|c|}{ Rural } \\
\hline & $\begin{array}{c}\% \text { of } \\
\text { House- } \\
\text { holds }\end{array}$ & $\begin{array}{c}\text { Share } \\
\text { of } \\
\text { Income }\end{array}$ & $\begin{array}{c}\text { Share } \\
\text { of } \\
\text { Taxes }\end{array}$ & $\begin{array}{c}\text { Effective } \\
\text { Tax } \\
\text { Rate }\end{array}$ & $\begin{array}{c}\% \text { of } \\
\text { House- } \\
\text { holds }\end{array}$ & $\begin{array}{c}\text { Share } \\
\text { of } \\
\text { Income }\end{array}$ & $\begin{array}{c}\text { Share } \\
\text { of } \\
\text { Taxes }\end{array}$ & $\begin{array}{c}\text { Effective } \\
\text { Tax } \\
\text { Rate }\end{array}$ \\
\hline$<200$ & 27.68 & 9.32 & 4.43 & 8.19 & 51.91 & 28.73 & 26.33 & 7.81 \\
\hline $200-499$ & 54.30 & 38.26 & 20.80 & 9.38 & 42.29 & 48.29 & 47.26 & 8.34 \\
\hline $500-1499$ & 13.73 & 23.44 & 18.63 & 13.71 & 4.36 & 12.52 & 13.32 & 9.07 \\
\hline $\begin{array}{c}1500 \text { and } \\
\text { above }\end{array}$ & 4.29 & 28.98 & 56.14 & 33.42 & 1.25 & 10.46 & 13.09 & 10.66 \\
\hline All Classes & 100 & 100 & 100 & 17.25 & 100 & 100 & 100 & 8.52 \\
\hline
\end{tabular}

Source : $[10$, p. 52$]$.

that the contribution of the rural sector in total tax revenue is 46.12 percent as compared to the contribution of 53.8 percent by the urban sector. With respect to indirect taxes, the rural component (55.73 percent) is even higher than the corresponding urban share ( 44.27 percent) $[10$, p. 23]. These results differ dramatically from those of an earlier study according to which the rural contribution to indirect taxes was substantially smaller-27 percent of the total $[24$, p. 6].

The reliability of Jeetun's results depends on the validity of his assumptions on the shifting of various taxes in the context of Pakistan's economy. The estimate of the incidence of indirect taxes derived in the study is based on the assumption that taxes on all commodities are shifted forward to the final consumers. Hence, the yield of each commodity tax is allocated between the two sectors in direct proportion to their respective expenditure on the taxed item. For taxes on intermediate and capital goods, the distribution of revenue is based on the ratio of sectoral expenditures on all manufactured goods. With respect to direct taxes, the income tax is assumed not to be shifted while fifty percent of the corporation tax is shifted forward to consumers. On the basis of available empirical evidence $[9 ; 12]$ on the shifting of indirect taxes for Pakistan and certain characteristics of the country's corporate sector, it is felt that the assumption of the shifting of indirect and corporation taxes is of questionable relevance and has led to an overestimate of agriculture's contribution to total taxes. Furthermore, the Jeetun study is limited to the incidence of federal taxes. Although federal taxes constitute the major portion of tax revenues, provincial taxes incorporate the only direct tax on agriculture. Hence, to get a complete picture it would be useful to look at the distribution of both federal and provincial tax revenues.

Finally, Jeetun's findings pertain to the rural and urban sectors while it is felt that in the context of the wider problem of the transfer of resources between sectors in the process of overall economic development a more relevant classification of tax incidence would be by the agriculture and non-agriculture sectors. Therefore, for the estimates presented in the following section the agriculture-non-agriculture dichotomy is used.

\section{AN ALTERNATIVE ESTIMATE OF THE CONTRIBUTION TO TAX REVENUE BY THE AGRICULTURAL AND NON-AGRICULTURAL SECTORS}

An attempt is made in this section to estimate the shares of the agricultural and non-agricultural sectors in both federal and provincial taxes on the basis of more appropriate assumptions on tax shifting covering the period from 1972-73 to 1979-80. The taxable capacity of the two sectors will also be calculated. These estimates, along with estimates of tax incidence, will be used to test the basis of overtaxation or undertaxation of the farm sector.

In keeping with the general view in fiscal theory that direct taxes are difficult to shift, it is assumed that direct taxes are borne by persons on whom they are imposed. Accordingly, land revenue and its various surcharges are assigned to the agricultural sector and the personal income tax to the non-agricultural sector.

The incidence of the corporation tax has been a subject of considerable controversy. Despite numerous studies for developed countries, the question of shifting is still not decided at either the theoretical or the empirical level. In the context of India, Gandhi [6] has put forward a strong case for the view that the burden of this tax rests with the business sector. ${ }^{2}$ The major point in the argument is that under monopoly situations, characteristic of Indian industry, a tax on profits is seldom shifted as the monopolist always charges the maximum price. A high degree of monopoly, attributable to a number of factors such as limited competition, licensing of new capacity, etc., is characteristic of the Pakistani business sector a well. A recent study $[1$, p. 275] shows that the nationalization of basic industries by the Bhutto government and the loss of assets in East Pakistan have made very little impact on the degree of concentration in the Pakistan industry. Hence, for the

${ }^{2}$ The assumption that the corporation tax is not shifted is accepted in nearly all other more recent empirical work on tax incidence in India [6, pp. 44-49;21, p. 23.] and the studies by Hamid [7] and Chaudhry [3] for Pakistan. 
purpose of this study the revenue from the corporation tax is allocated entirely to the non-agricultural sector.

Although there is no direct empirical evidence on the incidence of the corporation tax, there have been two studies $[9 ; 12]$ on the shifting of indirect taxes in Pakistan for the early Seventies. The findings of both the studies are very similar and show that whereas taxes on consumer goods are likely to be shifted almost fully to consumers, taxes on intermediate products display a very low degree of shiftability. On the basis of these results, revenue from indirect taxes on intermediate products is assigned to the non-agricultural sector while the yield of taxes on final products is divided between the farm and non-farm sectors in proportion to their total expenditure on various taxed items. Details of the procedure applied to calculate total sectoral expenditure on various commodities are provided in the Appendix.

Finally, export duties assumed importance as a source of revenue following the 1972 devaluation when they were imposed to siphon off windfall profits accruing to exporters as a result of the sharp increase in their exchange earnings. It seems quite likely that the tax would have been passed on to the foreign buyers owing to two reasons; firstly, because of the devaluation, the increase in domestic prices would not be fully reflected in world price and, secondly, the period under consideration was marked by a boom in the demand for primary products in the international market. Furthermore, from 1974-75 onwards, as a result of the subsequent slump in the world market, export duties were removed from most commodities. Hence, it can safely be assumed that the domestic producers did not bear the burden of these duties.

Data on taxes are taken from various issues of the Explanatory Memorandum on the Budget [14], Public Finance Statistics [15] and Federal Tax Administration Report [16]. Information on the methodology used for allocating various other central and provincial taxes (wealth taxes, estate duty, stamp and registration, etc.) between agriculture and the non-agricultural sector is given in the Appendix.

Estimates of incidence of direct, indirect and total taxes by the farm and nonfarm sectors are presented in Table 2. The results indicate that despite the larger agricultural population the share of the farm sector in tax revenues was lower than that of the non-farm sector for the entire period varying between a low of less than 21.5 percent of total tax revenue in $1972-73$ to a high of 27 percent of total taxes in 1973-74 and 1974-75. The smaller share of agriculture is attributable to the lower per capita income and the lower consumption expenditure on higher tax items such as petroleum products etc., while a much larger percentage of expenditure is devoted to food items which are exempt from taxation. Also, intermediate inputs, such as fertilizers and agricultural machinery, are imported free of duty.

Further disaggregation of the farm and non-farm shares of taxes into their direct and indirect tax components is presented in Table 3. The estimates not only

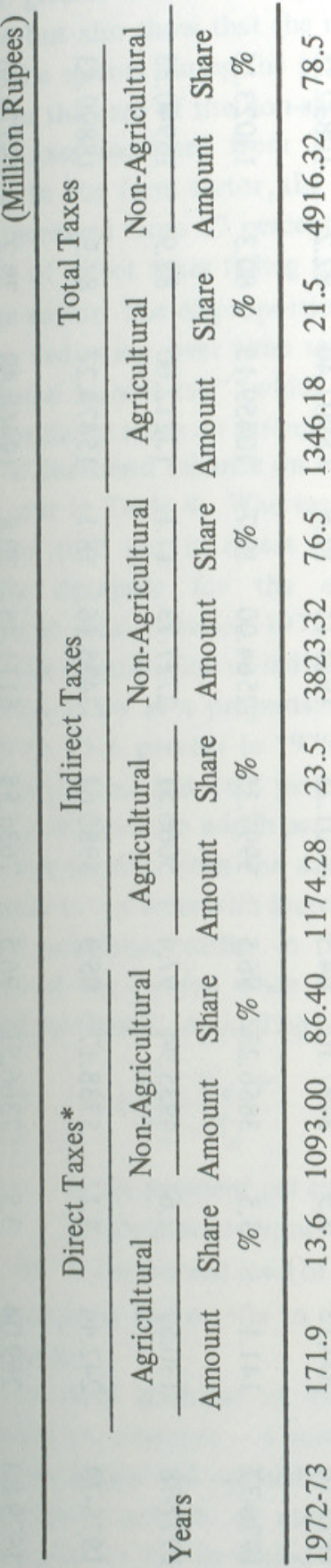

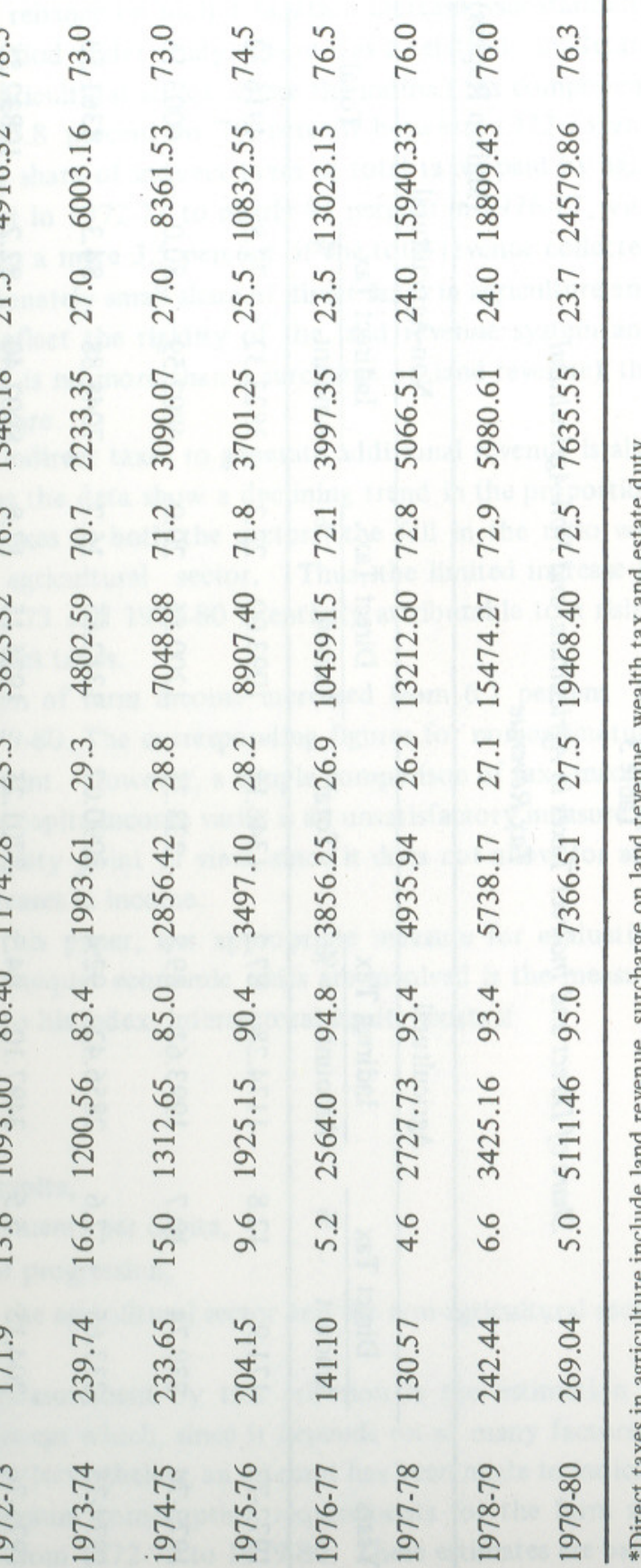


degree of dependence on indirect taxes in the agricultural tax but also show that the reliance on indirct taxation increased substantially the sectors during the period under study. There was a relatively moderate in both the sectors dare indirect tax component increase in the case of the 1972.73 and of total taxes increased frector, the share of indirect taxes in total taxes paid by agri1979-80. In the farm sector, the share of in 1972-73 to nearly 97 percent in 1976-77, with culture increased from 87 percent in $1972-73$ to nearly 97 percent in 197677 , with the share of direct taxes falling to a mere 3.5 percent of the total revenue collected from the sector. The disproportionately small share of direct taxes in ag its sharp reduction over time reflect the rigidity of the land revenue system and "agricultural income tax" (which is no more than a surcharge on land revenue), the two major direct taxes on agriculture.

The increased reliance on indirect taxes to generate additional revenue is also brought out in Table 4. Whereas the data show a declining trend in the proportion f income paid out in direct taxes in both the sectors, the fall in the ratio was especially dramatic for the agricultural sector. Thus, the limited increase in tax-income ratio between $1972-73$ and $1979-80$ is entirely attributable to a rising trend in the contribution of indirect taxes.

Total taxes as a proportion of farm income increased from 6.1 percent in 1972-73 to 11.6 percent in $1979-80$. The corresponding figures for non-agriculture were 12.6 percent and 16.8 percent. However, a simple comparison of tax-income ratios in a situation in which per capita income varies is an unsatisfactory measure of relative tax burden from the equity point of view, since it does not allow for any progression in tax rates with increases in income.

As mentioned earlier in this paper, the appropriate measure for evaluating intersectoral tax burden when unequal economic units are involved is the measure proposed by Gandhi. According to his index, intersectoral equity exists if

where

$$
\frac{t_{a}}{t_{n}}=\left(\frac{Y_{a}-S_{a}}{Y_{n}-S_{n}}\right)^{e o}
$$

$t$ is tax payment per capita,

$s$ is subsistence requirements per capita,

$e o$ is the desired level of progression,

and subscripts $a$ and $n$ refer to the agricultural sector and the non-agricultural sector respectively.

The main problem of measurement by this criterion is the estimation of subsistence requirement - a concept which, since it depends on so many factors, is difficult to define and calculate. Nevertheless, an attempt has been made to indicate roughly the magnitude of minimum consumption requirements for the farm and non-farm sectors for the period from $1972-73$ to $1979-80$. These estimates are based 
Table 4

Sectoral Taxes as percent of Sectoral Income

(Million Rupees)

\begin{tabular}{lcccccccc}
\hline Sectoral Taxes & $1972-73$ & $1973-74$ & $1974-75$ & $1975-76$ & $1976-77$ & $1977-78$ & $1978-79$ & $1979-80$ \\
\hline Agricultural & & & & & & & & \\
Income from Agriculture & 21907 & 28084 & 33533 & 38338 & 43686 & 49522 & 57497 & 66100 \\
Total Taxes & 1346.18 & 2233.35 & 3090.07 & 3701.25 & 3997.35 & 5066.51 & 5980.61 & 7635.55 \\
$\quad$ Direct Taxes & 171.9 & 239.74 & 233.65 & 204.15 & 141.1 & 130.57 & 242.44 & 269.04 \\
$\quad$ Indirect Taxes & 1174.28 & 1993.61 & 2856.42 & 3497.10 & 3856.25 & 4935.94 & 5738.17 & 7366.51 \\
Total Taxes as \% of Income & 6.1 & 8.0 & 9.2 & 9.7 & 9.2 & 10.2 & 10.4 & 11.6 \\
Direct Taxes as \% of Income & 0.8 & 0.9 & 0.7 & 0.5 & 0.3 & 0.3 & 0.4 & 0.4 \\
Indirect Taxes as \% of Income & 5.3 & 7.1 & 8.5 & 9.1 & 8.8 & 9.9 & 10.0 & 11.1 \\
& & & & & & & & \\
Non-Agricultural & & & & & & & & \\
Income from Non-Agriculture & 38888 & 52357 & 71107 & 83085 & 92000 & 107649 & 121561 & 146483 \\
Total Taxes & 4916.32 & 6003.16 & 8361.53 & 10832.55 & 13023.15 & 15940.33 & 18899.43 & 24579.86 \\
$\quad$ Direct Taxes & 1093.0 & 1200.56 & 1312.65 & 1925.15 & 2564.0 & 2727.73 & 3425.16 & 5111.46 \\
$\quad$ Indirect Taxes & 3823.32 & 4862.59 & 7048.88 & 8907.40 & 10459.15 & 13212.6 & 15474.27 & 19468.4 \\
Total Taxes as \% of Income & 12.6 & 11.5 & 11.8 & 13.0 & 14.2 & 14.8 & 15.5 & 16.8 \\
Direct Taxes as \% of Income & 2.8 & 2.3 & 1.8 & 2.3 & 2.8 & 2.5 & 2.8 & 3.5 \\
Indirect Taxes as \% of Income & 9.8 & 9.2 & 9.9 & 10.7 & 11.4 & 12.3 & 12.7 & 13.3 \\
\hline
\end{tabular}

Source: Figures for sectoral incomes are official estimates published in the Pakistan Economic Survey [17].

Table 5

Income per Capita, Minimum Consumption Requirements and

Taxable Capacity

$\begin{array}{llllllll}1972-73 & 1973-74 & 1974-75 & 1975-76 & 1976-77 & 1977-78 & 1978-79 & 1979-80\end{array}$

\section{Agricultural Sector}

Income per capita

Minimum Consumption Requirements

per capita

Taxable Capacity per capita

$\begin{array}{llllllll}618.4 & 771.9 & 897.4 & 999.1 & 1108.6 & 1224.3 & 1383.6 & 1550.6 \\ 306.8 & 429.9 & 543.8 & 581.0 & 639.9 & 686.5 & 719.5 & 778.5 \\ 311.7 & 341.9 & 353.6 & 418.1 & 496.2 & 537.8 & 664.1 & 772.0\end{array}$

Non-Agricultural Sector

Income per capita

$\begin{array}{llllllll}1303.6 & 1698.2 & 2231.6 & 2522.9 & 2702.9 & 3060.7 & 3343.2 & 3893.2\end{array}$

Minimum Consumption Requirements per capita

$\begin{array}{llllllll}439.9 & 611.7 & 771.9 & 830.0 & 915.7 & 979.6 & 1020.9 & 1103.9\end{array}$

Taxable Capacity per capita

$\begin{array}{llllllll}863.7 & 1086.5 & 1459.7 & 1693.0 & 1787.3 & 2081.2 & 2322.3 & 2789.3\end{array}$

Source: Sectoral population estimates are derived by distributing estimates of total population for the various years [25] on the basis of the information given in Labour Force Survey 1971-72 [19] on the classification of population by economic categories. 
on the results of a study by Wasay [23] in which minimum consumption requirements incorporating expenditure on food, clothing, housing, etc., were worked out for an average family for Rawalpindi on the basis of survey data for 1975. The estimate for Rawalpindi is assumed to be representative of the non-agricultural sector whereas the minimum subsistence requirements for the farm sector are assumed to be 70 percent of those of the non-farm sector.

The series of minimum consumption expenditure for the remaining years is derived by adjusting the 1975 estimate for variation in the price level. To make such adjustment, price index numbers were constructed for the agricultural and nonagricultural sectors with weights based on the consumption pattern of low-income households ${ }^{3}$ in the two sectors. Prices were taken from the CSO index of wholesale prices (Base Year 1969-70 = 100). The estimates of minimum consumption requirements per capita, income per capita and taxable capacity per capita are presented in Table 5 .

Finally, to test the thesis of undertaxation or overtaxation of the farm sector it is necessary to compare the relative tax burdens and the relative tax capacities of the farm and non-farm sectors. The equality of the two ratios indicates intersectoral equity in the incidence of taxation. If the relative taxable capacity ratio of the farm sector is greater than the relative tax burden ratio, then the farm sector is undertaxed.

The information provided in Table 6 shows that the relative taxable capacity of the farm sector has always been less than the relative tax burden for the period.

Table 6

Relative Tax Burdens compared with Relative Tax Capacity

\begin{tabular}{lccc}
\hline \multirow{2}{*}{ Years } & $\begin{array}{c}\text { Relative Tax Burden } \\
\text { (per capita) }\end{array}$ & \multicolumn{2}{c}{$\begin{array}{c}\text { Relative Tax Capacity } \\
\text { (per capita) }\end{array}$} \\
\cline { 3 - 4 } & & $e o=1$ & $e o=1.5$ \\
\hline $1972-73$ & 4.3 & 2.8 & 4.7 \\
$1973-74$ & 3.17 & 3.2 & 5.7 \\
$1974-75$ & 3.17 & 4.1 & 8.3 \\
$1975-76$ & 3.4 & 4.0 & 8.0 \\
$1976-77$ & 3.77 & 3.6 & 6.8 \\
$1977-78$ & 3.62 & 3.9 & 7.7 \\
$1978-79$ & 3.61 & 3.5 & 6.5 \\
$1979-80$ & 3.65 & 3.6 & 6.8 \\
\hline
\end{tabular}

${ }^{3}$ Income classes of less than Rs. 150 per month for the rural sector and of less than Rs. 200 for the urban sector. Information on consumption expenditure by' income groups was taken from [18].
On the average, the non-agricultural sector possessed taxable capacity (adjusted for progression) over six times that of the farm sector while the tax burden borne by the non-agricultural sector was only three and a half times that for the farm sector. Thus the thesis of the undertaxation of the farm sector is not supported by empirica evidence for the period from 1972-73 to 1979-80.

\section{CONCLUSIONS}

The direct findings of this study indicate that the agricultural sector bears a greater tax burden than is required for achieving intersectoral equity. However, the picture with respect to inter-class tax burdens between the two sectors is quite different. The evidence provided in an earlier work by Jeetun reveals that the highincome groups in the rural sector are grossly undertaxed as compared to their urban counterparts. Furthermore, as has been pointed out in this study, Jeetun's results are based on an overestimate of the rural contribution to total taxes and therefore the actual differential in inter-class tax burdens between the two sectors is likely to be even greater.

Evidence on the overtaxation of the agricultural sector as a whole in conjuction with undertaxation of the class of rich farmers points to the extreme regressivity of the agrarian tax structure. This is not surprising, given the virtual absence of any effective system of direct taxation for the sector. While the question of an agricultural income tax has become a point of great contention, the various governments have not hesitated to tax the agricultural sector through indirect taxation despite the negligible progressivity of the rurual tax structure. The tendency of an increased reliance on indirect taxes over time, characteristic of both the sectors, was especially noticeable in the case of agriculture. Thus, by 1979-80, nearly 97 percent of the tax revenue collected from the farm sector was in the form of indirect taxes while direct taxes as a proportion of agricultural income fell to the very low figure of 0.4 percent.

The especially poor performance of the agrarian tax structure with respect to direct taxes is traceable to the regressiveness and inelasticity of the land revenue system. Considerations of equity as well as the objective of surplus generation require replacement of the outmoded land tax structure with an effective direct tax on agricultural income. Although this fact has been recognized in nearly every official document related to the subject, there has been little attempt to implemen a thorough reform of the agrarian tax structure. Some minor cosmetic changes have been made over the years, yet the principle of taxation of agricultural income remains rejected. 
Table I

Shares of the Agricultural and Non-Agricultural Sectors in Total Expenditure on Various Commodities

\section{DISTRIBUTION OF THE BURDEN OF INDIRECT TAXES BETWEEN THE AGRICULTURAL AND NON-AGRICULTURAL SECTORS}

The revenue from indirect taxes on consumption goods is distributed between the two sectors on the basis of total expenditure on the taxed commodities in each sector (Table I).

The Household Income and Expenditure Survey (HIES) provides data on monthly consumption expenditure for rural and urban households on a number of commodities such as clothing, footwear, food, fuel and lighting, and other miscellaneous items. Information from HIES 1971-72 ( the latest available issue) is used in the calculations of intersectoral distribution of indirect taxes for the years from 1972 to 1979 on the assumption that there was no significant change in the pattern of consumption expenditure during the period.

To derive total expenditure on taxed commodities in the agricultural and nonagricultural sectors, a breakdown of rural and urban populations by economic categories is required. The Labour Force Survey published by the Central Statistical Office provides data on self-supporting persons in various economic categories as a proportion of rural and urban totals. This information is used to estimate the agricultural and non-agricultural populations in the rural and urban areas on the assumption that the distribution of population between different economic categories is in the same ratio as that of self-supporting persons.

The total value of expenditure on individual products by the agricultural sector is derived by multiplying the per capita expenditure on the product in the rural and urban sectors by the rural agricultural population and the urban agricultural population, respectively, and summing the totals. A similar procedure is used to derive the value of expenditure of the non-agricultural sector on various items.

The ratios of sectoral expenditure on various products are used to allocate taxes on items such as sugar, vegetable products, tobacco, tea, salt, clothing, footwear, etc. Taxes on electrical goods were divided in proportion to the expenditure on electricity in the two sectors. The sectoral expenditure on rent was the base for allocation of taxes on cement and paints and varnishes. The durable component of the expenditure on travelling was used to distribute taxes on vehicles while taxes on wood pulp, paper and stationery were divided on the basis of the expenditure on education in the two sectors. In cases where it was not possible to identify expenditure categories of taxed items such as rubber products, plastic products, etc., the ratio of sectoral expenditure on miscellaneous items was used.

In the case of petroleum products, additional information provided in an official publication was used (Table II). Tax yield for this category was allocated on the basis of these estimates of petroleum consumption by sectors. The proportion of
Share of

Share'of

Commodity

Agricultural Sector Non-agricultural Sector

Animal and Vegetable Products

\begin{tabular}{ll}
.375 & .625 \\
.49 & .51 \\
.45 & .55 \\
.51 & .49 \\
.32 & .68 \\
.34 & .66 \\
.52 & .48 \\
.52 & .48 \\
.42 & .58 \\
.19 & .81 \\
.53 & .47 \\
.50 & .50 \\
.10 & .90 \\
.43 & .57 \\
.49 & .51 \\
.33 & .67 \\
.37 & .63 \\
.12 & .88 \\
.40 & .60 \\
.45 & .55 \\
.47 & .53 \\
\hline
\end{tabular}

Tea and Coffee

51

Sugar

Salt

Cigarettes

Miscellaneous Food Items

Clothing

Footwear

Kerosene Oil

Electricity

Matches

Fuel and Light

Rent

Personal Care

Medical Care

Education

Travelling

Durable

Non-Durable

Fuel, Light and Conveyance

Miscellaneous Items

petroleum products for domestic use was further divided between the two sectors in the ratio of their expenditure on fuel and conveyance. Within the chemical products category taxes on industrial chemicals were assigned to non-agriculture (fertilizers are exempt from indirect taxation) whereas revenue from taxes on cosmetics and pharmaceutical products was distributed in the ratio of expenditure of the two sectors on medical and personal care.

Finally, taxes on iron and steel imports and machinery - agricultural machinery is imported free from duty - were allocated to the non-agricultural sector.

\section{Provincial Taxes}

Revenue from provincial excise, derived largely from intoxicants and alcoholic beverages, was divided in the ratio of the sectoral expenditure on miscellaneous food items. 
Table II

Sectoral Distribution of Petroleum Consumption

(Percent)

\begin{tabular}{lcc}
\hline Sector & $1964-65$ & $1973-74$ \\
\hline Domestic & 7.6 & 12.5 \\
Industry & 10.4 & 5.8 \\
Agriculture & 5.2 & 6.5 \\
Transport & 28.1 & 34.7 \\
Power & 1.0 & 5.4 \\
Other Government & 24.1 & 15.1 \\
Export & 21.6 & 19.5 \\
\hline
\end{tabular}

Source: $[13]$

Property and capital transactions involving nominal amounts have to bear registration and stamp fee. Assuming a direct relationship between transactions and income, the burden of these taxes is distributed in the same proportion as that of income in the two sectors.

Other provincial taxes consist largely of taxes that fall on the non-agricultural heads, e.g. taxes on cinemas and hotels, urban immovable property tax, profession tax, etc. Hence, only 10 percent of the yield of this category is assigned to agriculture.

\section{Wealth Tax, Estate Duty, and Gift Tax}

These taxes are characterized by high exemption limits and mostly fall on the very high income groups. Jeetun has derived the share in the rural and urban incomes of the highest income bracket, defined as the households earning Rs. 2000 or more per month, by adjusting the HIES data for the under-reporting of income of this class. Assuming an identical distribution of income in the agricultural and nonagricultural sectors, income accruing to this bracket in the two sectors is estimated. The revenue from the gift, wealth, and estate taxes is then divided between the farm and non-farm sectors on the basis of the proportions of the income of the richest strata in the two sectors.

\section{REFERENCES}

1. Amjad, R. "Industrial Concentration and Economic Power in Pakistan". In R. Ahmed et al. (eds.), Income Inequalities in Pakistan. Lahore: Punjab University Press. 1976.

2. Bird, R. M. Taxing Agricultural Land in Developing Countries. Cambridge, Mass.: Harvard University Press. 1974.

3. Chaudhry, M. G. "The Problems of Agricultural Taxation and an Alternative Solution”. Pakistan Development Review. Vol. XII, No. 2. Summer 1973.

4. Chelliah, R. J. Fiscal Policy in Underdeveloped Countries with Special Reference to India. London: George Allen \& Unwin. 1971.

5. Frank, H. J. "Measuring State Tax Burdens". National Tax Journal. December 1959.

6. Gandhi, V. Tax Burden on Indian Agriculture. Cambridge, Mass.: Harvard University Press. 1966.

7. Hamid, J. "Suggested Approach to Agricultural Taxation Policy in Pakistan". Pakistan Development Review. Vol. X, No. 4. Winter 1970.

8. Hunter, G. Modernizing Peasant Societies: A Comparative Study of Asia and Africa. London: Oxford University Press. 1969.

9. Irfan, M. "Shifting and Incidence of Indirect Taxes on Tobacco and Petroleum Products in Pakistan". Pakistan Development Review. Vol. XIII, No. 1. Spring 1974.

10. Jeetun, A. Incidence of Taxes in Pakistan. Karachi: Applied Economic Research Centre. 1978.

11. Khan, M. H. Under-development and Agrarian Structure in Pakistan. Boulder: Westview Press. 1981

12. Naqvi, B. "Formal Shifting of Indirect Taxes: A Further Study". Pakistan Development Review. Vol. XIV, No. 2. Summer 1975.

13. Pakistan. Directorate General of Energy Resources. Energy Yeark Book. Karachi. 1979.

14. Pakistan. Finance Division. Explanatory Memorandum on the Budget. Islam. abad. (Various issues)

15. Pakistan. Finance Division. Public Finance Statistics. Islamabad. (Various issues)

16. Pakistan. Finance Division. Federal Tax Administration Report. Islamabad, (Various issues)

17. Pakistan. Finance Division. Economic Adviser's Wing. Pakistan Economic Survey. Islamabad. (Various issues)

18. Pakistan. Statistical Division. Household Income and Expenditure Survey, Karachi. (Various issues)

19. Pakistan. Statistical Division. Labour Force Survey 1971-72. Karachi. June 973. 
20. Qureshi, S. K. "The Problem of Agricultural Taxation in West Pakistan and an Alternative Solution: A Comment" Pakistan Development Review. Vol. XII, No. 4. Winter 1973.

21. Shetty, S. L. "An Intersectoral Analysis of Taxable Capacity and Tax Burden”. Indian Journal of Agricultural Economics. July-September 1971.

22. Toye, J. F. J. (ed.), Taxation and Economic Development. London: Frank Cass. 1978.

23. Wasay, A. "An Urban Poverty Line Estimate". Pakistan Development Review. Vol. XVI, No. 1. Spring 1977.

24. World Bank. "An Analysis of Capital Flows between the Agricultural and Non-Agricultural Sectors of Pakistan”. Washington, D.C. 1969. (Economic Department Working Paper No. 4)

25. World Bank. Pakistan: Development Issues and Prospects. Washington, D.C. 1983. 